\title{
緩み領域の強度回復に関する基礎研究*
}

\author{
大久保誠介 ${ }^{1}$ 福 井 勝 則 $^{2}$ 杉 田 隆 博 $^{3}$
}

\section{Study on Strength Recovery of Loosen Zone}

by Seisuke OKUBO ${ }^{\mathrm{a}}$, Katsunori FUKUI ${ }^{\mathrm{a}}$ and Takahiro SUGITA ${ }^{\mathrm{a}}$

a. Department of Geosystem Engineering, The University of Tokyo, Bunkyo-ku, Tokyo 113-8656, Japan

Rock around an underground opening such as tunnel or gateway may fail. It is usually considered that loosen or damaged zone is gradually extending with elapsed time and stability is gradually decreasing.

Recently, it was pointed out that loosen zone might be recovered in strength under a proper condition. For example, if a tunnel is supported with a material of enough strength and stiffness, loosen zone between supports and surrounding rock is compacted and consolidated. Finally, the stability will be gradually increasing.

Very few studies on strength recovery of loosen zone or failed rock have been done up to now. In this study, strength recovery of Dotan (siltstone or mudstone), Tage tuff, Kimachi sandstone and Sanjome andesite is investigated by the following experimental procedures:

1) A sample rock (a cylindrical specimen) is inserted into a small pipe and then broken by a servo-controlled testing machine.

2) Load is increased to the predetermined value and then the broken rock is compacted in the pipe.

3) The compacted rock is pulled out from the pipe, and uniaxial compression and Brazilian tests are carried out.

The experimental results indicate that:

1) Strength recovery is verified in both uniaxial compression and Brazilian tests.

2) A degree of strength recovery varies from rock to rock. In Dotan, strength recovery is most remarkable among the 4 rocks. On the other hand, Sanjome andesite shows only poor strength recovery.

3) Strength recovery is much higher under air-dried condition than water-saturated condition.

KEY WORDS : Rock, Uniaxial Compressive Strength, Brazilian Test Strength, Compaction, Strength Recovery, Loosen zone

\section{1. は じめに}

トンネルや坑道などの地下構造物を設けたとき，その周辺の岩 盤は何らかの損傷を受ける。この損傷を受けた部分を以下では緩 み領域と称する。これまでの認識では, わずかずつではあるが, 時間の経過に伴ってこの緩み領域は次第に拡大していき，その結 果，坑道の安定性は低下寸るし，周辺の地下水の流動も活発にな ると考えられてきた。充分に注意して設計された地下構造物では, 時間経過に伴う緩夕領域の拡大や安定性の低下は, 多くの場合, 充分小さなものであろう。しかしながら，周辺の岩盤が次第に劣 化していくと考える限り，設けた地下構造物をかなりの期間にわ たって監視する必要があるので，経費の点で問題が生ずるし，何 年か後にどのような状態になるかを問われたとき，正確に回答す ることは困難である。

実際にトンネルや鉱山の坑道をはじめとする地下構造物では, 時間の経過に伴って次第に安定性が低下寸る場合もあるが，充分 な強度・剛性を持つ支保が施された場合には，緩み領域は時間の 経過に伴って回復し，領域が減少していく可能性があると著者は 考えている (大久保・福井, 1999 ; 杉田ら，2000)。著者の一人が

* 2001 年 4 月 19 日受付 6 月 6 日受理 資源・素材学会平成 11 年度および平 成 12 年度秋季大会において一部発表

1. 正会員 工博 東京大学教授 工学系研究科地球システム工学専攻

2. 正会員 工博 東京大学助教授 工学系研究科地球システム工学専攻

3. 東京大学大学院生 工学系研究科地球システム工学専攻 (現 JR 東海)

[著者連絡先] FAX 03-5841-7035 (東大・地球システム) E-mail : ttokubo@geosys.t.u-tokyo.ac.jp

キーワード : 岩石, 一軸圧縮強度, 圧裂引張強度, 圧密, 強度回復, 緩み領域
20 年ほど前に, 北海道夕張地区の炭坑で, 坑道の補修を見たと きのことを参考までに記しておく。この炭坑の運搬坑道は, 鉱車 (炭車) が充分な余裕をもって通過できるように掘られ, 初期の寸 法はおそらく横幅 $5 \mathrm{~m}$ で高さ $3.5 \mathrm{~m}$ 位であったと思う。これに鋼 アーチ支保が施されていたが, 数年の内に, 数 $10 \mathrm{~cm}$ 以上岩盤が 坑道内部に張り出してきた。そこで, 坑道の拡大をすることになっ た。ちょうどそのとき, 著者の一人が炭坑を訪れ見学した。他箇 所の観測結果より類推すると, 掘削した直後は, 鋼アーチ支保の 裏側には細かい岩片が詰まっているという状態であったと考えら れる。それが数年を経た後にはかなり硬くなり，ピック（小型さ く岩機 ) で掘り進むのに困難を感ずるまでに硬化していた。図 1 に示すように, 一旦緩んだ坑道周辺の岩盤に, 内からは支保の反 力が加わり, 外からは地圧が加わって, 緩み領域の強度回復が進

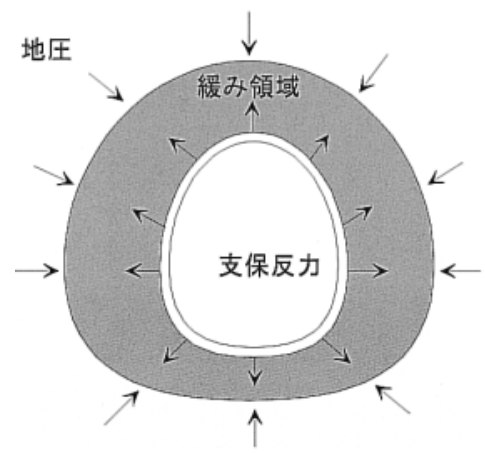

図 1 坑道周辺の模式図 


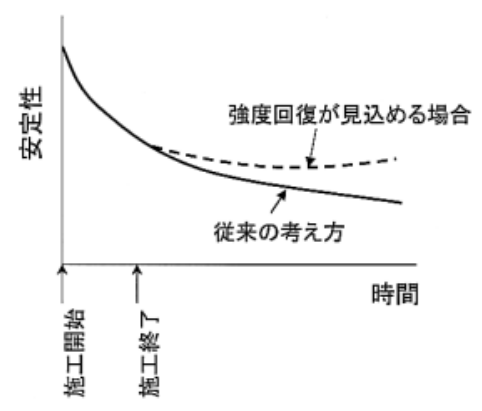

図 2 坑道の安定性の経時変化
表 1 試料岩石の物性値

\begin{tabular}{|c|c|c|c|c|c|c|}
\hline \multirow{2}{*}{\multicolumn{2}{|c|}{ 试料岩石 }} & \multirow{2}{*}{ 胃かけ比重 } & \multirow{2}{*}{ 空暸率(\%) } & \multicolumn{2}{|c|}{ 一軸圧縮試験 } & \multirow{2}{*}{$\frac{\text { 圧翌引張詰騃 }}{\text { 強度( }(\mathrm{MPa})}$} \\
\hline & & & & 強度 $(\mathrm{MPa})$ & ヤング率 $(\mathrm{GPa})^{*}$ & \\
\hline 土丹 & 自然含水状怊 & 1.6 & 41 & 5.2 & 0.74 & 0.65 \\
\hline \multirow{2}{*}{ 田下㠜灰岩 } & 気乾状態 & \multirow{2}{*}{1.7} & \multirow{2}{*}{30} & 33 & 4.3 & 2.2 \\
\hline & 湿潤状態 & & & 16 & 2.6 & 1.3 \\
\hline \multirow{2}{*}{ 来待眇岩 } & 気乾状態 & \multirow{2}{*}{2.0} & \multirow{2}{*}{25} & 54 & 6.3 & 3.4 \\
\hline & 湿润状態 & & & 32 & 5.0 & 2.2 \\
\hline \multirow{2}{*}{ 三城目安山岩 } & 気乾状態 & \multirow{2}{*}{2.2} & \multirow{2}{*}{14} & 110 & 9.2 & 7.4 \\
\hline & 湿潤状態 & & & 82 & 7.2 & 3.1 \\
\hline
\end{tabular}

行した可能性が強いと考えている。このように掘削直後に広がっ た緩み領域に，適切な支保が施された場合には，時間の経過に伴 い縮小していく。図 2 に示すように, その結果として, 坑道の安 定性も増していく可能性があるとの考えが, 本研究の原点である。

緩み領域の強度回復に関連する研究は少ないが, Dieterich (1972 a, b) は, せん断試験において, 滑り面と垂直に荷重をかけて おくと, 時間経過に伴って, 滑りはじめのせん断抵抗 (摩擦抵抗) が上昇していくと報告している。また, Smith and Evans (1984)は, 高温・高圧下で, 結晶中にできた微小亀裂が回復 (healing) してい くことがあると報告している。両者とも, 今回の研究とはかなり 異なる条件下での研究結果ではあるが, 強度回復が, 場合によっ てはありえることを示している例と考えたので紹介した。

本研究では強度回復に関寸る研究の第一歩として, 岩石試験片 を一度圧縮破壊させた後に, 厚肉円筒中で再度圧縮する。その後, 厚肉円筒から取り出した試験片の一軸圧縮強度および圧裂引張強 度，破断面の状況等について調べた結果を報告する。

\section{2. 試料岩石と実験方法}

\section{$2 \cdot 1$ 試料岩石と試験片}

試料岩石として, 土丹, 田下凝灰岩, 来待砂岩, 三城目安山岩 の 4 種類を用いた。土丹は, 横浜市下水道局栄処理区東俣野幸浦 線 ( 第一工区) 下水道整備工事現場で採取した。採取地点の土被 りは約 $50 \mathrm{~m}$ であり, 切り出した岩石ブロックの寸法は $20 \mathrm{~cm} \times 20$ $\mathrm{cm} \times 45 \mathrm{~cm}$ であった。岩石ブロックは濃灰色でやや緑色を帯びて おり, 表面全体が濡れていたので, 採取後直ちに濡れた布で包み, さらにビニール袋に入れて密封した。田下凝灰岩, 来待砂岩, 三 城目安山岩は石材店から購入したもので, 各岩石ブロックの寸法 は $10 \mathrm{~cm} \times 30 \mathrm{~cm} \times 45 \mathrm{~cm}, 30 \mathrm{~cm} \times 30 \mathrm{~cm} \times 30 \mathrm{~cm}, 20 \mathrm{~cm} \times 20 \mathrm{~cm} \times$ $45 \mathrm{~cm}$ であった。

三城目安山岩のブロックは流理面が明瞭であったので，これと 垂直にボーリングした。他の岩石ブロックの方向性は不明瞭で あったので，方向性を考慮しないでボーリングした。ボーリング したコアより, 直径 $25 \mathrm{~mm}$, 高さ $25 \mathrm{~mm}$ で, 上下端面間平行度士 $0.05 \mathrm{~mm}$ の円柱形試験片を作成した。

土丹の試験片は自然含水状態を維持するために, 湿った布に包 んだ後さらにビニール袋に入れて保存し, 試験直前にビニール袋 から取り出して試験に供した。他の 3 岩石は, 気乾状態と湿潤状 態で試験をした。気乾状態の試験は, 試験片を温度 $25^{\circ} \mathrm{C}$, 湿度 65 $\pm 15 \%$ に空調管理された実験室内に 2 週間以上保管した後に行っ た。湿潤状態の試験は, 真空ポンプで空隙中の空気を抜いた試験 片を, イオン交換水中に 2 週間以上漬けた後に行った。表 1 に試 料岩石の物性值を示す。

\section{$2 \cdot 2$ 押し込み試験方法}

載荷装置として $1,500 \mathrm{kN}$ サーボ試験機 (MTS 社製) を使用した。
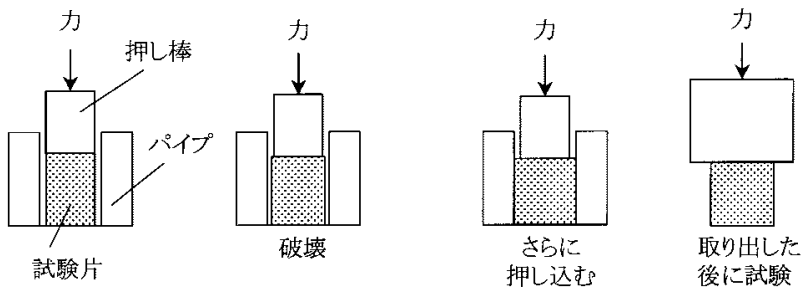

図 3 押し込み試験の手順

まず，図 3 のように試験片を外径 $50 \mathrm{~mm}$, 内径 $27 \mathrm{~mm}$ の鋼製厚 肉円筒に入れ, 直径 $25 \mathrm{~mm}$ の押し棒によって変位速度 $5 \times 10^{-3}$ $\mathrm{mm} / \mathrm{s}$ ( 歪速度 $2 \times 10^{-4} / \mathrm{s}$ ) で押し込む。試験開始時の試験片側面と 厚肉円筒内壁の間には充分な隙間があるので, 一軸圧縮応力下で 試験片は載荷され, やがてピーク強度に達する。ピーク強度を過 ぎてからもなお押し棒を押し込むと, 試験片は横に膨らんでいき, やがて試験片側面が厚肉円筒内壁と接触し, 荷重が増加し始める。 その後も, 所定の押し込み最大荷重に達するまで押し棒を押し込 み続ける。押し込み最大荷重に達したら試験機を止めて, 試験片 を取り出す。この試験では, 厚肉円筒と押し棒との間に充分な隙 間 (初期值 $1 \mathrm{~mm}$ ) があるので, 試験片に含まれていた水がこの隙 間を通って出てくることがあった。したがって, 排水条件下での 試験と見なしてよい。

押し込み最大荷重は, $19.6,39.2,58.8,78.4 \mathrm{kN}$ の 4 条件とし たが，以下の文中ではそれぞれ $20 ， 40,60,80 \mathrm{kN}$ と呼ぶ。これ らの荷重を試験片の初期断面積で割ると, 約 40, 80, 120,160 $\mathrm{MPa}$ となる。深さ $1,000 \mathrm{~m}$ の地中でも初期応力は $25 \mathrm{MPa}$ 程度と 考えられるので, 今回加えた押し込み最大荷重はかなり大きめで あるが, 強度回復の有無をできるだけ短時間で調べるためにこの ように設定した。なお, 原則として同一条件で 5 回, 最低でも 3 回の試験を行った。

試験中, 歪ゲージ式ロードセルで荷重を, 差動変圧器で変位を 測定した。さらに, 歪ゲージで, 厚肉円筒外壁の周方向歪を測定 し, 次式を用いて厚肉円筒内壁に加わる側圧 (内圧) を計算した (日本機械学会, 1994)。

$$
p_{i}=\varepsilon_{\theta} E\left(r_{o}^{2}-r_{i}^{2}\right) / 2 r_{i}^{2} \times\left(h / h_{t}\right)
$$

ここで, $p_{i}$ は側圧, $\varepsilon_{\theta}$ は周方向歪, $E$ は厚肉円筒のヤング率, $r_{o}$ は厚肉円筒外径, $r_{i}$ は厚肉円筒内径, $h$ は厚肉円筒高さ, $h_{t}$ は試験 片高さである。

押し込み試験の後に, 厚肉円筒から取り出した試験片を用いて, 一軸圧縮試験 (変位速度 $5 \times 10^{-3} \mathrm{~mm} / \mathrm{s}$ ) と圧裂引張試験 ( 変位速度 約 $5 \times 10^{-3} \mathrm{~mm} / \mathrm{s}$ ) を行った。載荷装置としては, 一軸圧縮試験で は $1,500 \mathrm{kN}$ サーボ試験機 (MTS 社製) を, 圧裂引張試験では $10 \mathrm{kN}$ 万能試験機 ( 東京衡機製造所製) を使用した。なお, 圧裂引張試 験では球座を使用した。 


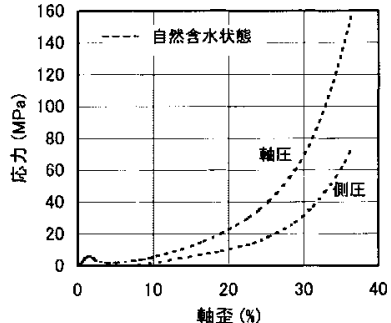

(a) 土丹

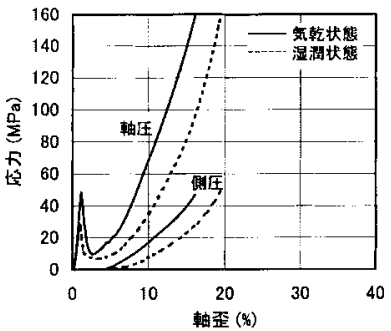

(c) 来待砂岩

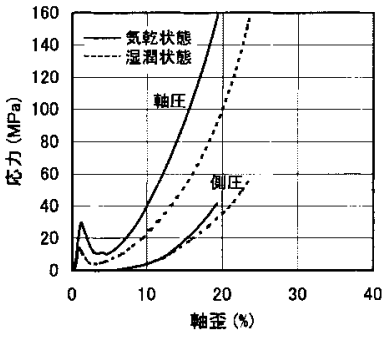

(b) 田下疑灰岩

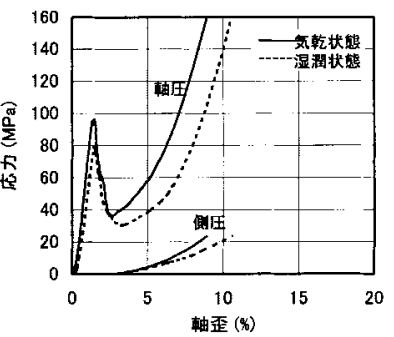

(d)三城目安山岩

図 4 押し込み試験における応力一歪曲線。いずれも押し込み 最大荷重は $80 \mathrm{kN}$

\section{3. 押し込み試験結果}

図 4 に押し込み最大荷重 $80 \mathrm{kN}$ のときの応力一歪曲線を示す。 横軸に軸歪 (試験片軸方向の歪) をとり, 軸圧 (試験片軸方向の応力 ) と側圧を示した。軸歪の最大值は $40 \%$ 近くにまで達するが，簡 明さを重んじて, 軸歪は初期長さを基準とし, 軸圧は初期断面積 を基準として計算した。すなわち, 微小歪のときと同じ計算方法 で軸歪と軸圧を求めた。したがって, みかけの軸歪，みかけの軸 圧と称するのが正しいが, 煩雑さを避けるため以下では単に軸歪, 軸圧とする。

図 5 に, 押し込み試験後に厚肉円筒から取り出した試験片の体 積を, 試験前の試験片体積で割った值を示した。また, 図 6 と表 2 には，それぞれ押し込み試験後の試験片の写真と, 試験片の概 況を示す。

土丹の試験結果を，図 4(a) と図 5(a) に示す。図 4(a) を見ると, ごく初期の間，軸圧は上昇するがすぐに低下寸る。やがて，軸歪 が $4 \%$ 付近で軸圧は最低となり, その後は軸歪が増加するに従っ て軸圧も増加していく。厚肉円筒外壁の周方向歪から計算した側 圧は，軸歪の小さい間零であるが，軸歪が $7 \%$ を超えたあたりか ら徐々に増加する。軸歪が $20 \%$ 以上になると, 軸圧も側圧も次第 に上昇率を増していき，両曲線は顕著に下に凸となる。押し込み 最大荷重に達したときの軸歪は $30 \%$ 以上で, 他の岩石に比べてか なり大きい。また，このときの側圧は，軸圧の約 $50 \%$ であり，こ れも他の岩石に比べて大きい。図 5(a) を見ると，すべての押し込 み最大荷重において, 押し込夕試験後の体積が，初期試験片体積 より小さいことがわかる。これから考えて，土丹においては，含 まれていた水が排出されることもあって，体積の収縮が速やかに 進行したと考えられる。

図 6 と表 2 を参照しつつ, 押し込み試験後に取り出した土丹の 試験片の特徴について述べることにする。もつとも顕著な点は, 試験片の端面, 側面とも滑らかで亀裂などは観察できなかったこ とである。ただし，下面の周縁は面取りをしたような状況であっ た。これはどの岩石にも共通していた。下面の周縁は，厚肉円筒 内壁と試験機の下面が交差する隅の部分であり, 強度の回復が起 こり難い箅所であること, また, 押し込み試験後に試験片を取り 出寸ときには, この部分が最初に取り出されるので剥ぎ取られや

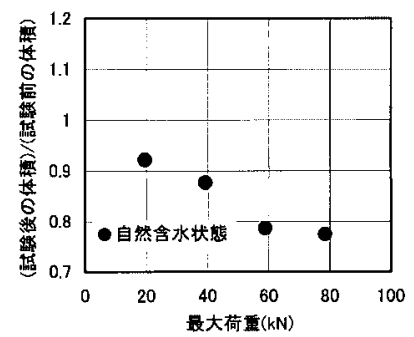

(a) 土丹

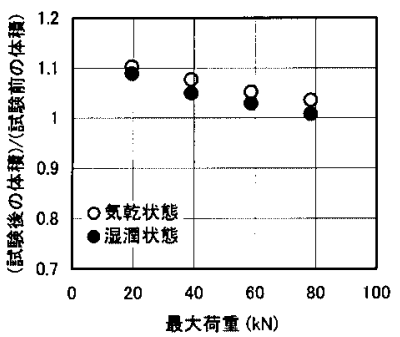

(c) 来待砂岩

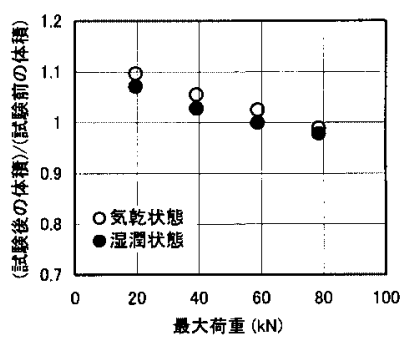

(b) 田下凝灰岩

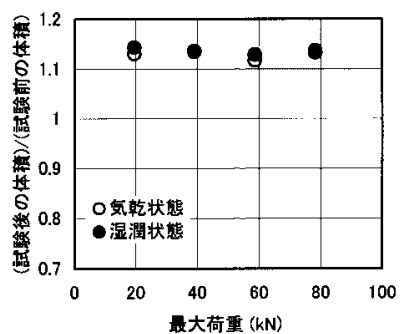

(d) 三城目安山岩
図 5 押し込み試験後に取り出した試験片の体積 (平均值)

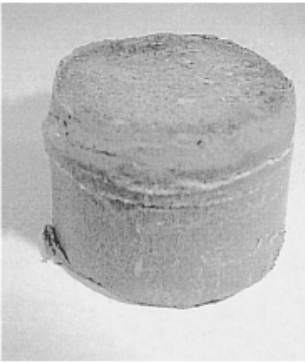

(a) 土丹

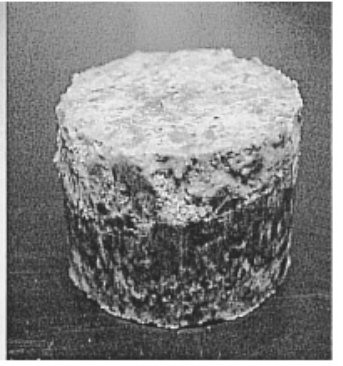

(b) 田下凝灭岩

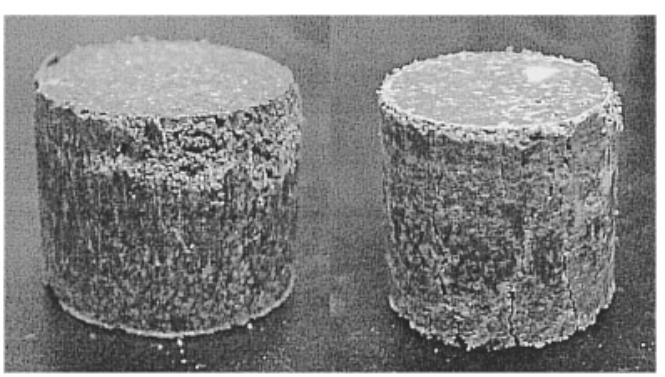

(c) 来待砂岩

図 6 押し込夕試験後に厚肉円筒から取り出した試験片。 湿潤状態で，押し込み最大荷重は $80 \mathrm{kN}$

すかったことによるものである。なお，図６に示したのは，押し 込み最大荷重 $80 \mathrm{kN}$ のときの写真であるが，押し込み最大荷重が 低いときの傾向もほぼ同じであった。

図 4(b) に, 気乾と湿潤状態の田下凝灰岩の応力一歪曲線を示す。 気乾状態の方が一軸圧縮強度は高く, 湿潤状態のときの約 2 倍で あった。軸歪が増しても, 気乾状態のときの応力一歪曲線は常に, 湿潤状態の上であった。気乾状態と湿潤状態の側圧の差はわずか であったが，この場合にも気乾状態のときの曲線が常に湿潤状態 の上にあった。気乾状態, 湿潤状態とも定性的な傾向は土丹の場 合と変わらないが，全般的に軸歪は小さめであった。たとえば， 湿潤状態で押し込み最大荷重に達したときの軸歪は $23 \%$ であり土 丹に比べて相当に小さい。図 5(b) に示した体積変化を見ると, 押 し込み最大荷重が 20 と $40 \mathrm{kN}$ では押し込み試験終了後の試験片体 
表 2 押し込み試験後に厚肉円筒から取り出した試験片 (上)，取り出した試験片の一軸圧縮試験後の試験片 (中), 圧裂試験後の試験片 (下) の概況

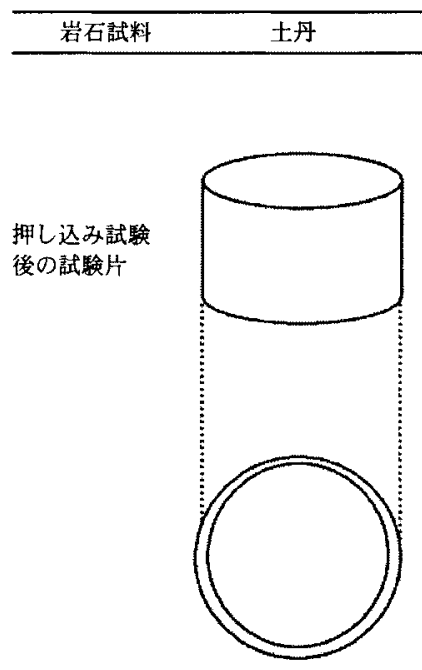

側面，端面とも，試験前 より色の濃さを増し，滑 らかでひび割れは無い。 下面の周緑は, 面取りを したような状況であり。 これは他の岩石でも同様 である

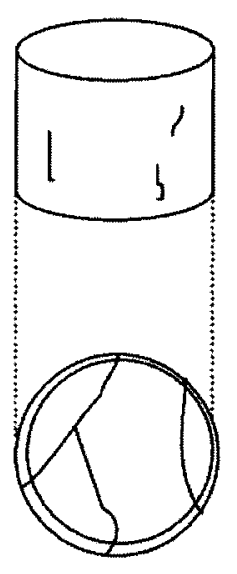

側面，端面の凹凸は軽 側面，端面の凹凸は軽 微、側面には短いひび 微、側面には顕著なひ 割れが，下面には幅の び割れが，下面には幅 狭いひび割れが見られ の狭いひび割れが見ら

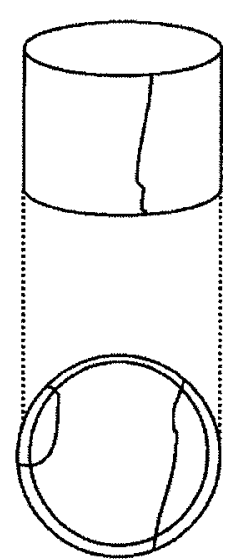

れる 三城目安山岩

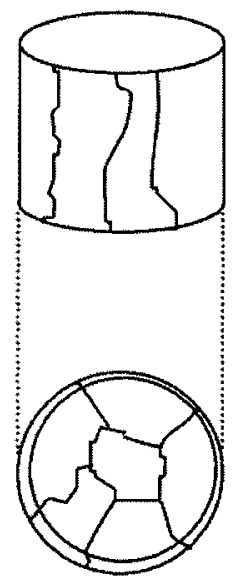

側面には多くの縋割れ がみられ, 臲く剥離し 易い。下面にも顕著な ひび割れが見られ，下 面中心部が少し盛り上 がっている

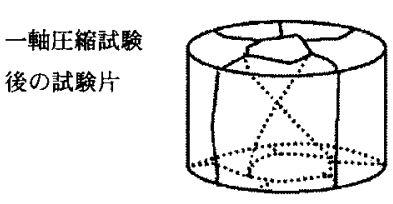

小さなコーンが両端に 出来ており，それを起 点とする緥割れが出来 ている

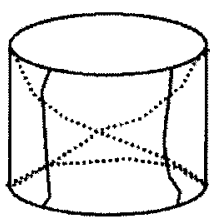

コーンが藏端に出来 る. 側面には数本の維 割れが出来る

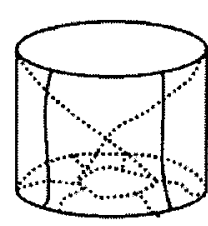

コーンが両端に出来る が, 片方は小さくなって いる場合あり．それを困 むように側面には数本の 綎割れが出来る

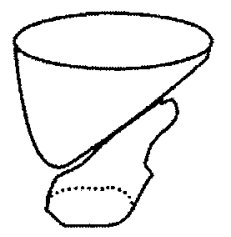

せん断面が出来てお り, せん断面に法摖過 痕あり.側面は，はがれ 易い

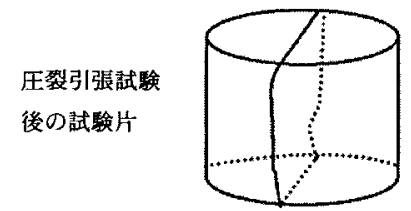

通常の压裂引張武験 片で見られるのと似 た破断面が出来る

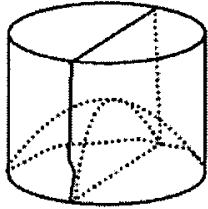

通常の破断面に加えて コーンに治った破断面 が出来る

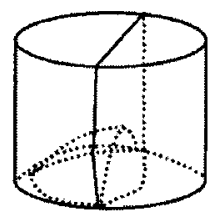

由下疑灰岩とほほ同じ，両端のコーンがそのま ただしコーンが強固な場 ま残り，その周りの部 合が多以

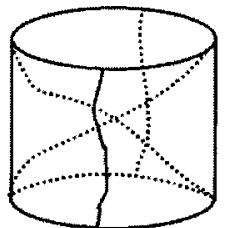

分が半分になる
積は, 最初の試験片体積より大きいことがわかる。押し込み最大 荷重が $60 \mathrm{kN}$ では，気乾状態，湿潤状態とも試験前後の体積がほ ぼ同じになっている。押し込み最大荷重 $80 \mathrm{kN}$ に至って初めて, 試験後の体積の方が小さくなった。このように，田下凝灰岩では， 土丹に比べて，小さな歪で押し込み最大荷重に達し，試験片体積 の収縮もあまり進まないことがわかった。図 6 と表 2 を見ると, 厚肉円筒から取り出した試験片の端面と側面には，若干の凹凸が 見られるものの比較的滑らかであった。側面には亀裂が見られた が, 縦方向で比較的短い亀裂が少数存在するのみであった。試験
片端面の内, 下面にはかなり長い亀裂がしばしば見られたが, 亀 裂は閉じており, 肉眼でやっと観察できるほどの幅の狭い亀裂で あった。

図 4(c) に示す来待砂岩の応力一歪曲線は, 田下凝灰岩とさほど 変わらなかった。ただし, 全般的に軸歪が小さくなっていること がわかる。また，側圧についても定性的な傾向は変わらないが， 気乾状態と湿潤状態との差が，田下凝灰岩に比べてやや大きかっ た。図 $5(\mathrm{c})$ に示寸体積変化は, 田下凝灰岩よりさらに押し込み試 験による体積の収縮が進まないことがわかる。押し込み最大荷重 
が $80 \mathrm{kN}$ のときでも，試験後の体積は試験前より増加していた。 押し込み試験後に取り出した試験片の端面，側面の凹凸は軽微で あり田下凝灰岩と同等であった。ただし，側面には少数ではあっ たが，上面から下面まで貫く亀裂が入っていることがあった。ま た，試験片の下面には亀裂の見られることがあったがその頻度や 長さは田下凝灰岩より少なく短い。端部には, 他岩石と比較して 強固な円錐 (コーン) が残存することが多かった。

三城目安山岩は，今回試験をしたなかではもっとも一軸圧縮強 度の大きな岩石であった。図4(d) の応力一歪曲線は定性的には他 岩石と同じであったが，軸歪はかなり小さかった。また，発生す る側圧も他岩石より小さかった。さらに，図 5(d) からわかるよう に, 押し込み最大荷重が増しても体積はほとんど変化しなかった。 厚肉円筒から取り出した三城目安山岩の試験片の側面と端面には 多くの長い亀裂が見られた。亀裂の中には, 口を開いているもの もあり，強く押すと岩片が剥離する。これらから考えて，三城目 安山岩においては, 強度の回復はあまり期待できないとの印象を 受けた。なお, 他の岩石では, どちらかというと気乾状態の試験 片の方が硬く締まった感じであったが，三城目安山岩だけは，気 乾状態の方が，表面から小さな岩片が落ちやすかった。湿潤状態 では, 水の表面張力により, 小さな岩片が張り付いている可能性 がある。

\section{4. 厚肉円筒から取り出した試験片の強度}

\section{$4 \cdot 1$ 一軸圧縮強度 (押し込み試験後 )}

厚肉円筒から取り出した試験片を用いて一軸圧縮試験を行っ た。図 7 に応力一歪曲線を, 図 8 に一軸圧縮強度と押し込み最大 荷重の関係を示寸。また, 表 3 には, 押し込み試験後に取り出し た試験片の物性值を示す。

図 7(a) は, 自然含水状態における土丹の応力一歪曲線である。 試料岩石と試験後の物性值を記した表 1 と表 2 を参照しつつ検討 を進める。応力一歪曲線は，ばらつきが大きかったが，押し込み 最大荷重が大きいほど, 一軸圧縮強度が高くやや脆性的となった。 試験後の試験片を見ると，中央に小さな円錐ができており，この 円錐部分が貫入してできたと思われる亀裂が端面より放射状に延 びて側面に至っていることが多かった。土丹において最も特徴的 であるのは, 試料岩石の一軸圧縮強度が $5.17 \mathrm{MPa}$ (平均值) であっ

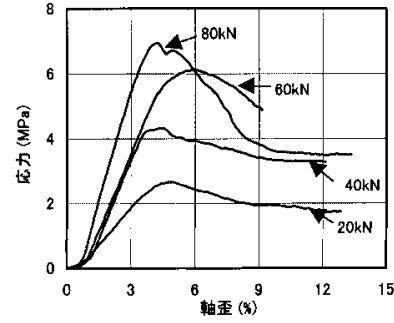

(a) 土丹

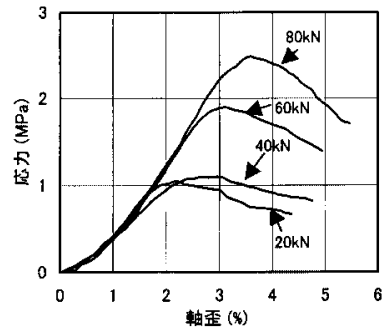

(c) 来待砂岩

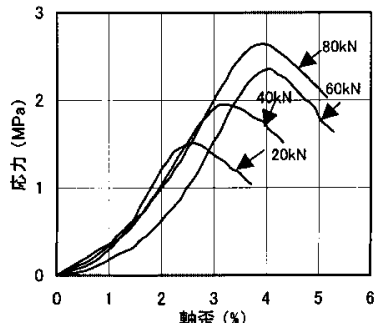

(b) 田下凝灰岩

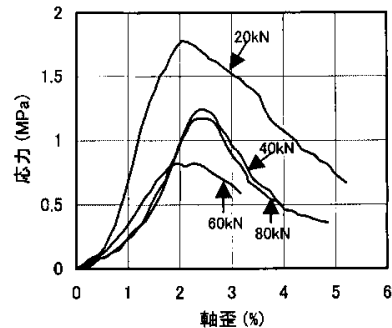

(d) 三城目安山岩
図 7 応力ー歪曲線。押し込み試験後に厚肉円筒から取り出した試験片 の一軸圧縮試験による。土丹は自然含水状態で，他は湿潤状態
たのに対して，押し込み最大荷重で $80 \mathrm{kN}$ 試験後の一軸圧縮強度 が $8.4 \mathrm{MPa}$ (平均值) に達していることである。このように土丹に おける強度の回復は著しいものであった。ただし，ここで注意し ておきたいのは, 試料岩石のヤング率が $0.74 \mathrm{GPa}$ であったのに対 して, 押し込み最大荷重で $80 \mathrm{kN}$ 試験後のヤング率は $0.24 \mathrm{GPa}$ と かなり小さいことである。押し込み試験後の試験片には，平たく 変形しや寸い微小亀裂が多数含まれているためと考えられる。他 の岩石でも, 押し込久試験後の試験片のヤング率は, 試料岩石の ヤング率に比べて顕著に小さいのは, 同様の理由によるものと考 える。

図 7(b) に, 湿潤状態の田下凝灰岩の応力一歪曲線を示す。押し 込夕最大荷重が増加するにつれて一軸圧縮強度が増加するのがわ かる。しかしながら, 応力ー歪曲線の立ち上がり部分の傾きは, 押し込夕最大荷重によってあまり変化しないことがわかる。強度 破壊点以降の傾きは，押し込夕最大荷重により大きな変化は見ら れなかった。なお，ここで示さなかった気乾状態の応力ー歪曲線 は, 一軸圧縮強度とヤング率が高いことを除いて, 定性的には湿 潤状態と同様の傾向であった。気乾状態と湿潤状態の応力ー歪曲 線が，定性的には同様の傾向を示したのは，以下で述べる来待砂 岩でも三城目安山岩でも同様であったので, 両者とも湿潤状態の 応力ー歪曲線のみを示した。一軸圧縮試験後の試験片を見ると, 両端に円錐ができることが多く, 側面には明膫な縦割れが観察で きた。図 8(b) には, 押し込み最大荷重による一軸圧縮強度の変化 を示したが，これからわかるように気乾状態の方が全般的に強度 が大きいことがわかる。殊に, 押し込み最大荷重が $80 \mathrm{kN}$ では 3 倍強に達している。

図 7(c) には, 来待砂岩の応力一歪曲線を示す。田下凝灰岩と似 た応力ー歪曲線であり立ち上がりの曲線の傾きが, 押し込み最大 荷重にあまりよらない点も同じである。図 8(c) に示寸傾向も田下 凝灰岩と似ており, さらにその值自体も似通っていることがわか る。破壊後の試験片についても, 両端面に円錐ができること, ま た, 側面には数本の縦割れが見られることなど, 田下凝灰岩とさ ほど変わった様子は見られなかった。一軸圧縮強度に関しては, 田下凝灰岩と来待砂岩とはかなり似た結果を与えるといってよか ろう。

図 7(d) に示寸三城目安山岩では, これまでの 3 岩石とかなり

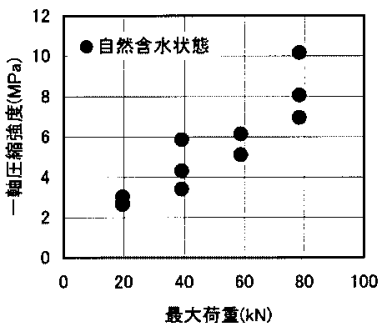

(a) 土丹

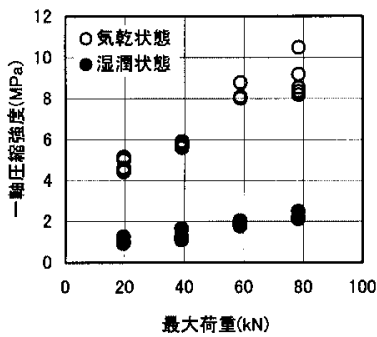

(c) 来待砂岩

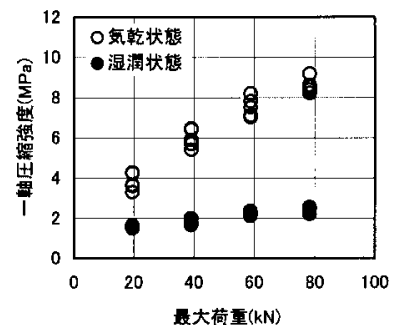

(b) 田下凝灰岩

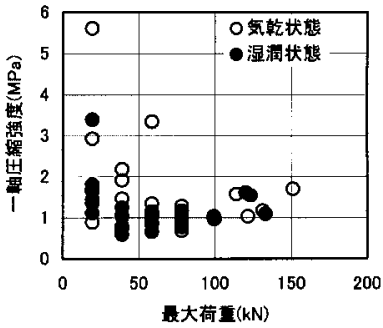

(d)三城目安山岩
図 8 一軸圧縮強度。横軸は, 押し込み最大荷重。押し込み試験後 に厚肉円筒から取り出した試験片の一軸圧縮試験による。 
表 3 押し込み試験後に取り出した試験片の物性值

\begin{tabular}{|c|c|c|c|c|c|c|c|c|c|c|c|c|}
\hline \multirow{2}{*}{\multicolumn{2}{|c|}{ 岩䅜 }} & \multirow[b]{2}{*}{$\begin{array}{c}\text { 最大荷重 } \\
(\mathbf{k N})\end{array}$} & \multicolumn{3}{|c|}{ ヤング率* } & \multicolumn{3}{|c|}{ 一軸圧縮強度 $\sigma_{c}$} & \multicolumn{3}{|c|}{ 圧裂柘張強度 $\sigma_{t}$} & \multirow[b]{2}{*}{$\sigma_{\mathrm{c}} / \sigma_{\mathrm{t}}$} \\
\hline & & & $\begin{array}{l}\text { 平均値 } \\
(\mathrm{GPa})\end{array}$ & $\begin{array}{c}\text { 標準偏差 } \\
(\mathrm{GPa})\end{array}$ & $\begin{array}{c}\text { 変動係数 } \\
(\%)\end{array}$ & $\begin{array}{l}\text { 平均值 } \\
(\mathrm{MPa})\end{array}$ & $\begin{array}{c}\text { 標準偏善 } \\
(\mathrm{MPa})\end{array}$ & \begin{tabular}{|c|} 
変動係数 \\
$($ (x)
\end{tabular} & $\begin{array}{l}\text { 平均值 } \\
(\mathrm{MPa})\end{array}$ & 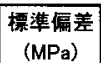 & \begin{tabular}{|c|} 
变動係数 \\
$(\%)$
\end{tabular} & \\
\hline \multirow{4}{*}{ 土丹 } & \multirow{4}{*}{ 自然含水状愳 } & 19.6 & 0.085 & 0.020 & 24 & 2.8 & 0.21 & 7.4 & 0.46 & 0.13 & 29 & 6.1 \\
\hline & & 39.2 & 0.14 & 0.020 & 14 & 4.5 & 1.2 & 27 & 0.81 & 0.16 & 20 & 5.6 \\
\hline & & 58.8 & 0.13 & 0.034 & 28 & 5.5 & 0.59 & 11 & 0.87 & 0.12 & 14 & 6.3 \\
\hline & & 78.4 & 0.24 & 0.070 & 29 & 8.4 & 1.6 & 19 & 1.1 & 0.24 & 21 & 7.5 \\
\hline \multirow{8}{*}{ 田下赫灰岩 } & \multirow{4}{*}{ 気乾状態 } & 19.6 & 0.37 & 0.037 & 10 & 3.8 & 0.43 & 11 & 0.23 & 0.055 & 24 & 17 \\
\hline & & 39.2 & 0.44 & 0.025 & 5.6 & 6.0 & 0.45 & 7.5 & 0.25 & 0.035 & 14 & 24 \\
\hline & & 58.8 & 0.47 & 0.024 & 5.1 & 7.5 & 0.50 & 6.6 & 0.34 & 0.035 & 10 & 22 \\
\hline & & 78.4 & 0.47 & 0.015 & 3.2 & 8.6 & 0.36 & 4.2 & 0.36 & 0.044 & 12 & 24 \\
\hline & \multirow{4}{*}{ 湿潤状態 } & 19.6 & 0.10 & 0.0075 & 7.6 & 1.6 & 0.070 & 4.5 & 0.10 & 0.014 & 14 & 16 \\
\hline & & 39.2 & 0.085 & 0.011 & 13 & 1.9 & 0.14 & 7.6 & 0.091 & 0.013 & 14 & 20 \\
\hline & & 58.8 & 0.091 & 0.0076 & 8.3 & 2.2 & 0.094 & 4.2 & 0.10 & 0.010 & 9.3 & 21 \\
\hline & & 78.4 & 0.093 & 0.0074 & 8.0 & 2.5 & 0.16 & 6.6 & 0.12 & 0.010 & 8.9 & 21 \\
\hline \multirow{8}{*}{ 来待眇岩 } & \multirow{4}{*}{ 気乾状態 } & 19.6 & 0.47 & 0.027 & 5.8 & 4.7 & 0.31 & 6.5 & 0.52 & 0.063 & 12 & 9.2 \\
\hline & & 39.2 & 0.51 & 0.030 & 5.9 & 5.7 & 0.12 & 2.1 & 1.0 & 0.21 & 21 & 5.7 \\
\hline & & 58.8 & 0.62 & 0.086 & 14 & 8.2 & 0.32 & 4.0 & 0.95 & 0.18 & 19 & 8.6 \\
\hline & & 78.4 & 0.57 & 0.089 & 16 & 9.0 & 0.94 & 10 & 1.3 & 0.12 & 9.2 & 6.9 \\
\hline & \multirow{4}{*}{ 湿潤状態 } & 19.6 & 0.064 & 0.012 & 20 & 1.0 & 0.13 & 12 & 0.17 & 0.043 & 26 & 6.3 \\
\hline & & 39.2 & 0.064 & 0.0083 & 13 & 1.3 & 0.22 & 18 & 0.25 & 0.016 & 6.3 & 5.0 \\
\hline & & 58.8 & 0.091 & 0.0064 & 7.0 & 1.9 & 0.11 & 5.9 & 0.33 & 0.018 & 5.5 & 5.7 \\
\hline & & 78.4 & 0.082 & 0.0074 & 9.0 & 2.2 & 0.18 & 8.0 & 0.34 & 0.032 & 9.3 & 6.4 \\
\hline \multirow{8}{*}{ 三城目安山岩 } & \multirow{4}{*}{ 気乾状態 } & 19.6 & 0.28 & 0.23 & 81 & 2.5 & 1.9 & 76 & - & - & - & - \\
\hline & & 39.2 & 0.14 & 0.063 & 43 & 1.4 & 0.64 & 45 & - & - & - & - \\
\hline & & 58.8 & 0.14 & 0.092 & 65 & 1.6 & 1.0 & 65 & - & - & - & - \\
\hline & & 78.4 & 0.078 & 0.022 & 28 & 0.91 & 0.23 & 25 & 0.34 & 0.15 & 44 & 2.7 \\
\hline & \multirow{4}{*}{ 湿潤状態 } & 19.6 & 0.17 & 0.12 & 72 & 1.9 & 0.88 & 47 & 0.24 & 0.074 & 30 & 7.7 \\
\hline & & 39.2 & 0.063 & 0.021 & 33 & 0.93 & 0.26 & 28 & 0.17 & 0.053 & 31 & 5.4 \\
\hline & & 58.8 & 0.059 & 0.026 & 44 & 0.87 & 0.21 & 24 & 0.16 & 0.059 & 38 & 5.6 \\
\hline & & 78.4 & 0.063 & 0.018 & 29 & 0.98 & 0.14 & 15 & 0.23 & 0.081 & 36 & 4.3 \\
\hline
\end{tabular}

違った結果となった。まず，押し込み最大荷重がもっとも小さい $20 \mathrm{kN}$ で，一軸圧縮強度が最大となった。押し込み最大荷重を 40 $\mathrm{kN}$ すると一軸圧縮強度はかえって小さくなり, その後, 押し込み 最大荷重を $80 \mathrm{kN}$ まであげても一軸圧縮強度はほとんど変わらな かった。試料岩石の一軸圧縮荷重がもっとも大きな三城目安山岩 では，押し込み最大荷重が $80 \mathrm{kN}$ という值は相対的に小さすぎる のではないかと考えてそれ以上に設定した試験を行った。押し込 み最大荷重が $100 \mathrm{kN}$ 以上になると一軸圧縮強度はあがるがその程 度は少なく, 今回行った試験条件下における, 三城目安山岩の強 度回復は小さかった。さて, この一軸圧縮試験後の試験片におい ても破断面はやや異なっていた。表 2 に示すように, 側面が大き く剥がれ落ち, 最終的にはせん断面に沿った破壊が生じたと思わ れる。せん断面には擦過痕が認められ，かなりの距離のせん断す べりが生じたことがわかる。なお, 田下凝灰岩と来待砂岩では, 気乾状態の圧縮強度の方がかなり大きかったが, 三城目安山岩の 一軸圧縮強度は, 気乾と湿潤状態とで差が認められなかった。

図 9 の横軸は, 湿潤状態の押し込夕試験において, 押し込み最 大荷重を加えたときの軸歪である。また, 縦軸は, 押し込み試験 後の一軸圧縮強度である。これを見るとだいたいどの岩石も一つ の下に凸の曲線上にのっている。これから即断するのは難しいが, 軸歪を測定することで一軸圧縮強度を知ることができる可能性が あるといえよう。ただし, 図の左端に位置する三城目安山岩だけ

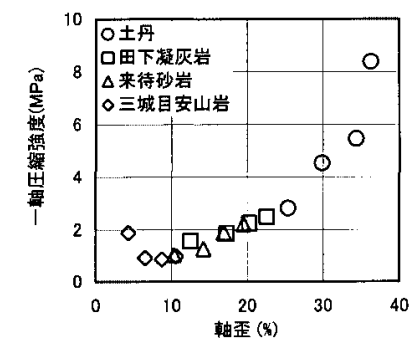

図 9 押し込み試験後の一軸圧縮強度。横軸は, 押し込み最大 荷重を加えたときの軸歪。湿潤状態
は, 軸歪が増加するとかえって一軸圧縮強度が低下寸る傾向も見 られた。この場合には, 軸歪が $20 \mathrm{kN}$ から $40 \mathrm{kN}$ に増すと, 試料 岩石の組織が壞れていく影響の方が, 回復より大きいのであろう。 なお, 気乾状態の結果は示さなかったが, 定性的な傾向は湿潤状 態とさほど変わらなかった。

一軸圧縮強度は, 押し込み最大荷重や側圧とも相関があると考 えられる。しかしながら, ヤング率や体積弾性率などの弾性定数 が岩石ごとに異なるので, すべての試料岩石を同じ図に描くと, 試料岩石ごとにかなり異なる。

\section{$4 \cdot 2$ 圧裂引張強度 (押し込み試験後)}

厚肉円筒から取り出した試験片を用いて圧裂引張試験を行っ た。図 10 に圧裂引張強度と押し込み最大荷重の関係を示す。

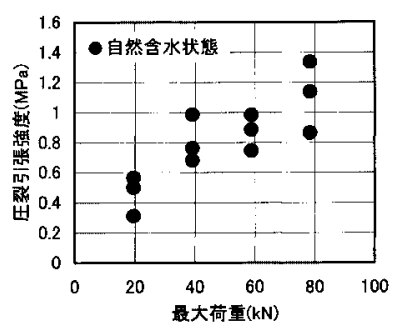

(a) 土丹

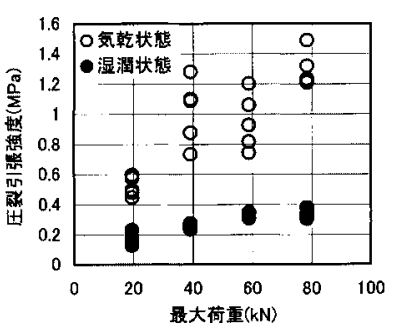

(c) 来待砂岩

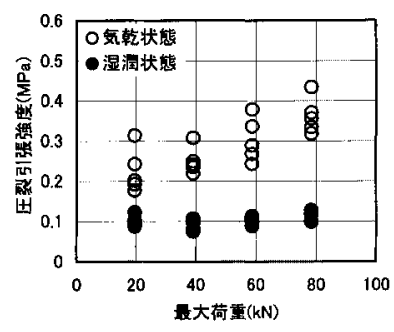

(b) 田下凝灰岩

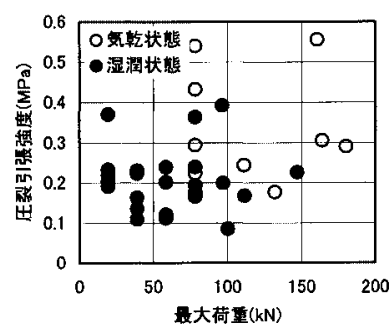

(d)三城目安山岩
図 10 圧裂引張強度。横軸は, 押し込み最大荷重。押し込み試験 後に厚肉円筒から取り出した試験片の圧裂引張試験による 
図 10(a)に示寸土丹では, 押し込み最大荷重の増加に伴って, 圧 裂引張強度は単調に増加する。その増加率は, 4 岩種の中では一 番大きい。最大荷重 $40 \mathrm{kN}$ では, 試料岩石の圧裂引張強度よりも 大きな值となった。試験後の試験片を見ると, 通常の圧裂引張試 験でもっともしばしば見られるように，載荷点を結んだ破断面が 形成されていた。

図 10(b) と (c) には，それぞれ田下凝灰岩と来待砂岩の結果を示 す。両者に共通していえることは，気乾状態の值の方が大きいこ とである。ただし，かなりのばらつきがあった。湿潤状態の圧裂 引張強度は小さいが，值のばらつきは比較的小さかった。ここで 注目すべきことは，定性的な傾向は似ているが，来待砂岩と比較 して田下凝灰岩の圧裂引張強度が一貫して小さいことである。一 軸圧縮強度の場合には，両者の差は比較的小さかったことを考え ると何らかの原因がありそうに思われた。そこで, 圧裂試験後の 試験片を調べてみると，田下凝灰岩では，土丹の場合と同じよう に, 載荷点を結ぶ破断面が形成されているのに対して, 来待砂岩 では，両端の強固な円錐をできる限り迂回するような破断面が形 成されることが多かった。おそらく，来待砂岩では，比較的強固 な円錐が試験片両端に残りやすく，このため圧裂引張強度が高く でたのであろう。

図 10(d) に三城目安山岩の結果を示す。まず, 三城目安山岩の 気乾状態では, 試験片の側面が剥離しや寸く, 押し込み最大荷重 が $20 \sim 60 \mathrm{kN}$ までの圧裂引張試験は実施できなかった。湿潤状態 では，す心゙ての押し込み最大荷重で圧裂引張試験が実施できた。 図からわかるように，圧裂引張強度は，他岩石と比べてばらつき が大きかった。また，押し込み最大荷重に伴って上昇する傾向も なかった。試験後の試験片を見ると，両端には円錐が残るが，側 面は真二つに割れて剥離する。強固な両端の円錐部分と，わずか な力でくっついている側面とが, 試験前に共存していたと考える。

一軸圧縮強度と同様に，圧裂引張強度と軸歪の間にもある程度 の相関があったが，圧縮強度の場合よりは小さな相関係数であっ た。

\section{5. 考察}

土を対象とした土質工学の分野では，衝撃的な力を加えて土を 締め固め (compaction), 基礎地盤や路床として適当な強度を持たせ ることに関する研究が行われている(たとえば河上, 1997 ; 石原, 1998)。しかしながら，研究の対象は，当然ながら N 值で評価され るような土である。また, 圧密 (consolidation) に関する研究も行わ れてきたが，土を対象として，ずっと低い応力下での検討が中心 であり，この場合には水圧が負担する力が支配的であることから 考えても，本研究との直接の関連は薄いと思う。

土木工法の中には, 締固め工法ないし圧密工法と呼ばれる多数 の工法がある (産業調查会, 2001)。現場での経験により編み出さ れたものが多く，それらの原理・原則は明らかでないが，本研究 ともっとも近いのはおそらく静的締固め工法と思われる。しかし ながら, この場合にも, あくまでも対象は土であり, これと本研 究との直接の関連は薄いと思う。

地質学でいう続成作用の中には，a）粒子の再配置，b) 粒子の塑 性変形，c）細粒の粘土などが流動して隙間を埋める圧密作用（地 質学では compaction), d) 炭酸塩鉱物などで膠結される膠結作用, e) 再結晶作用, f) 交代作用, g) 差別的溶解作用, h) 圧力溶解作用 (応力腐食)，i）自生作用などが含まれる (たとえば水谷ら，1999； 勘米良ら，1991）。a)～c) は本研究でも生じていたと考える。一 方，d）以下は，かなり長期間にわたる場合に限って，重大な意味 を持つと考えられ，今回の実験でこれらがどの程度の役割を果た
していたかは今のところわからない。

今回の試験における強度回復と関わると思われる点を挙げてお $<$ 。

(1) 食い込み：圧裂引張試験後の試験片の破面を見ると, 食い 込んだ部分が剥ぎ取られたような窪みが観察できた。形状は丸み を帯びて半球に近く, 大きいもので, 径 $2 \mathrm{~mm}$, 深さ $1 \mathrm{~mm}$ 程度で あった。これは, 金属が疲労破壞したときにあらわれるディンプ ル (dimple) に似ていた。これから考えて, 破砕された岩片の間で, 相互の食い込みは生じていたと思う。

(2) 粘着性のある物質の介在 : たとえば粘土ないしそれに類し たものが，破片と破片の間に入り込む可能性がある。これは，地 質学でいう続成作用のc) と通じるところがある。

今回使用した土丹は, 土丹の中ではもっとも強度の高い部類に入 るが，表面は比較的柔らかく，爪で押すとわずかではあるが寉む。 細かい粒子より構成されており, 小片を手で触って押した感触で は, 粘土ほどではないが塑性変形しやすかった。厚肉円筒に入れて 押すと小さなピーク強度で破壊する。押し込み最大荷重が $80 \mathrm{kN}$ のときには, 歪が $30 \%$ を超える。この押し込み過程において, 押 し棒と厚肉円筒の間の隙間から試験片に含まれていた水が漏れ出 てきた。押し込み試験後の試験片体積が減少したのは, 水の流出 によるところが大きいと思われた。また側圧が軸方向応力の $50 \%$ にも達したことから考えて, おそらく, 破片の塑性変形とそれに 伴う構成粒子の再配置とがかなり生じたと考える。圧裂試験後の 試験片の破面は比較的滑らかで凹凸は少なかった。(1)食い込み は，大小様々なスケールで生じている可能性があると考えている。 しかしながら, 肉眼で観察できる範囲では, 明瞭な食い込みの痕 は見つからなかった。土丹の場合には, おそらく, (2)の効果が大 きいのではないかと思うが，現段階では推測の域をでない。

田下凝灰岩と来待砂岩では, 土丹と比較して側圧が小さいこと から判断して, 押し込み試験中の破片の塑性変形や再配置は, 土 丹に比べて少なかったといえる。田下凝灰岩の圧裂引張試験後の 試験片は，載荷点を結ぶ面を破面として壊れることが多かった。 できた破面には，(1)で述べた，食い込んだ部分が剥ぎ取られたよ うな痕がしばしば見られた。来待砂岩でも同様の観察はできたが, 田下凝灰岩よりは数が少なかった。これらの岩石では, 程度の差 はあるが，(1)の効果は期待できそうである。(2)がどの程度貢献し ているかについては, 現時点では, わからない。

”はじめに”で, 著者が夕張地区の炭坑で経験し, この研究を はじめる契機になったことを記した。ほぼ同じ頃, 同様に著者の 一人が経験したことで, おそらく深いところで今回の強度回復の テーマと結びついている可能性があることをこの機会に披露して おく。旋盤などの工作機械を用いて, 軟鋼やアルミニウムなどを 切削すると, その先端に切り屑が強固に固着し, 次第にあたかも 鼻のような形に成長することは, 構成刃先 (Built-up-nose) と称せ られるよく知られた現象である (竹中，1968)。また，土が鋤やス コップの先端にくつつくことも, 古くからよく知られている（最 上，1974）。著者の一人が，いくつかの岩石を用いて切削実験を 行っていたところ, 特に, 先端の丸い Point-Attack 式ビットでは, 先端に岩石がこびりつくことがあった。ビット先端部は岩石と直 接あたる。岩石がこびりつくのは，おそらく高い圧力で金属面に 押し付けられたためであろう。さらに, 同じ箇所に, 岩石がこび りついて成長していくことが観察された。もっとも, いつまでも 成長するわけではなく, ある程度の高さになると, 曲げ応力で折 れてしまう。実験室実験であっても, 重切削を一定期間行うと刃 先の温度は数百度まで上がるが, この構成刃先の形成は, 必ずし も高い刃先温度を必要としなかった。この場合にも, 刃先で一旦 
粉砕された岩片 ( 岩粉) が非常に硬く固着するわけであり，今回 の研究ともある程度結びつくのではないかと考える。

\section{6. ま と め}

本研究で行った実験を行う前に，適当な実験方法について，か なりの期間にわたって検討した。その経緯を少し紹介しておく。 図 1 を参照すればわかるように, 坑道壁面の岩石は, 周方向の応 力で破壊した後, 適切な支保が施されると半径方向の応力を受け て強度が回復していく。これをできる限り忠実に再現する手段を 種々考えたが，結局良い方法が見つからず，今回提案した方法で 試験を実施した。今回の試験では、押し込み試験および押し込み 試験後の強度試験を通じて, 荷重方向が一致しており, さらに試 験機と接する面も同じなので，試験片端部に円錐形の強度の高い 部分が残る傾向が，土丹を除いて見られた。その結果，例えば， 圧裂引張強度が高めにでるなどの弊害が生じた可能性が高いと考 えている。今回の試験法で，強度回復しやすい岩石を見出し，そ の程度を何段階か（例えば 4 〜 段階）に分類することまではで きそうである。今後の展開を見なければ判断できないが, 強度回 復まで含めた構成方程式の構築などの基礎データとするには, 試 験方法に一工夫を要するかもしれない。

本研究では，4 種類の岩石を用いて押し込み試験を行った。そ の後, 厚肉円筒から取り出した試験片について一軸圧縮試験と圧 裂引張試験を行い, 強度回復が確認できるかを調べた。その結果, 土丹, 田下凝灰岩, 来待砂岩では強度回復が確認でき, その程度 は押し込み試験における最大荷重，軸歪，側圧と関係があること がわかった。特に土丹は，押し込み最大荷重が大きいと試料岩石 の強度を超えた。一方で三城目安山岩については, 押し込み最大 荷重を $100 \mathrm{kN}$ 以上にしても, 強度が回復していく傾向はほとんど 見られなかった。強度回復の程度は, 岩石ごとにかなり異なると いえよう。残念ながら, 各岩石のどのような性質が強度回復にど の程度かかわってくるかについては不明である。

試験を実施する前には，土の締め固めが先入観としてあり，粒 子表層の電気二重層等の影響で (最上，1974)，湿潤状態の方が強 度回復しやすいのではないかと予測した。この点は, 今回実験し た岩石に関しては，逆の結果を得た。すなわち，これまで行って きた通常の試験と同様に, ヤング率も強度も気乾状態の方が大き かった。

本研究の応用として, 例えば高レベル放射性廃棄物をはじめと する廃棄物の地下処分場の長期安定性がある ( 核燃料サイクル機 構，1999）。処分場の安定性に対して一般の理解を得ること, また 高い見識を持った専門家を充分に納得させる必要があることを考
えると, 周辺岩盤が次第に弱くなっていきいつかは壊れてしまう とのストーリーは容易でない。このストーリーでは, 壊れるがそ れは充分長い時間の経過後であるから, 心配ないとの説明に終始 することになるだろう。その際, 坑道の寿命を議論・検討し, あ る程度定量的な結論を得る必要があるが，これは相当に困難と思 われる。他方, 緩み領域の強度が回復することが確かになれば, ど のくらいの速度でどのように回復していくか等の定量的な議論は さほど重要で無くなる。ただ単に, やがて回復が見込めることの みを明示することができれば，それで充分に説得力があるし真実 に近いと考えている。実際, ドイツ使用済み燃料中間貯蔵施設候 補地 Gorleben では, 従来から知られている岩塩の快癒 (healing) と それに伴う浸透率の低下が期待されている (Cristescu and Hunsche, 1999)。

本論文で示したのは，これから予定している強度回復に関する 研究の第一歩である。今回行った試験の問題点の一つは, 実際に 想定されるより大きな押し込み荷重で短時間の試験しか行わな かったことである。強度回復の途上では力学的作用の他に化学的 作用が生じている可能性が高い。化学作用には, 荷重により加速 されるものと, 反応速度が荷重に左右されにくいものがあるが, 今回の実験では後者に関する検討はなされていない。その結果, 本研究で示した強度回復の機構は, 実際の場合と異なる可能性を 否定できない。したがって, 本研究で提案した試験は, 建設予定 地の粗調査の段階で強度回復の高低を推し量ることはできるかも しれないが，追ってより実際の地圧などの状況に則した試験をす る必要があろう。今後の課題としては，押し込み荷重がより低い 状態で長時間の実験を行い, 時間依存性について明らかにするこ とが挙げられよう。

\section{引用文 献}

Cristescu, N. D. and Hunsche, U. (1999) : Time Effects in Rock Mechanics, § 2.2, John Wiley \& Sons (Chichester, England)

Dieterich, J. H. (1972a) : JGR, Vol. 77, No. 20, p. 3690-3697

Dieterich, J. H. (1972b) : JGR, Vol. 77, No. 20, p. 3771-3781

石原研而 (1998) : 土質力学，第 3 章と第 6 章，丸善 (東京)

核燃料サイクル機構 (1999) : 地層処分研究開発第 2 次取りまとめ (第 2 分冊) 第 4 章 第 3 節, JNC TN1400 99-022

勘米良亀齢・水谷伸治郎・鎮西清高（1991）：地球表層の物質と環境，p. 35-49，岩

波 (東京)
河上房義 (1997) : 土質力学, 第 6 章と第 12 章, 森北出版 (東京)

水谷伸治郎, 斎藤靖二, 勘米良亀齡 (1999) : 日本の堆積岩, 第 2 章, 岩波 (東京)

最上武雄 (1974) : 土質力学, 第 5 章, 岩波 (東京)

日本機械学会 (1994) : 機械工学便覧”材料力学”, p. 71, 丸善 (東京)

大久保誠介・福井勝則 (1999) : 資源・素材 ' 99 ( 京都) 資料, 講演番号 A1-5, p. 9-10

産業調査会 (2001) : 土木工法事典, p. 321-328, 産業調査会 (東京)

Smith, D. L. and Evans, B. (1984) : JGR, Vol. 89, No. B6, p. 4125-4135

杉田隆博・大久保誠介・福井勝則 (2000) : 資源・素材 2000 ( 秋田) 講演資料, 講演番 号 A3-13, p. $135-136$

竹中規雄 (1968)：機械製作法 (2),p. 10-11，コロナ社 (東京) 